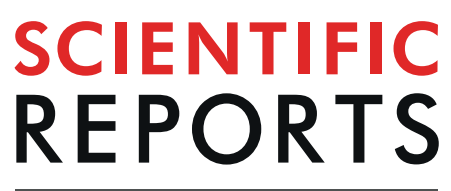

natureresearch

\title{
OPEN
}

Published online: 20 November 2019

\section{Author Correction: Mating of escaped domestic pigs with wild boar and possibility of their offspring migration after the Fukushima Daiichi Nuclear Power Plant accident}

\section{Donovan Anderson, Rio Toma, Yuki Negishi, Kei Okuda, Hiroko Ishiniwa, Thomas G. Hinton, Kenji Nanba, Hidetoshi B. Tamate \& Shingo Kaneko}

Correction to: Scientific Reports https://doi.org/10.1038/s41598-019-47982-z, published online 08 August 2019

This Article contains an error in Table 2 where the frequency of hybrid (H1) haplotype detection before FDNPP accident and after (2014-2018) partitioned by Difficult-to-Return zones (20-40 km) is incorrect.

The correct value should read 4(14\%).

(1) Open Access This article is licensed under a Creative Commons Attribution 4.0 International C. License, which permits use, sharing, adaptation, distribution and reproduction in any medium or format, as long as you give appropriate credit to the original author(s) and the source, provide a link to the Creative Commons license, and indicate if changes were made. The images or other third party material in this article are included in the article's Creative Commons license, unless indicated otherwise in a credit line to the material. If material is not included in the article's Creative Commons license and your intended use is not permitted by statutory regulation or exceeds the permitted use, you will need to obtain permission directly from the copyright holder. To view a copy of this license, visit http://creativecommons.org/licenses/by/4.0/.

(c) The Author(s) 2019 